senerally nearly intermediate in character between their two parents; but in the next generation the offspring commonly revert to one or both of thetr grandparents, and occasionally to more remote ancestors" (vol. ii., p. 383).

The somatic cells of the hybrid, according to the theory of pangenesis, throw ott gemmules carrying the character-units, and, as Darwin says, "by the same hypothesis dormant gemmules derived from both pure parent-forms are likewise present. . . ."

"Consequently," he continues, " the sexual elements of a hybrid will include both pure and hybridised gemmules; and when two hybrids parr, the combination of pure gemmules derived from the one hybrid, with the pure gemmules of the same parts derived from the other, would necessarily lead to complete reversion of characters" (ibid.).

Here we have as exact a presentation of the allelomorphic idea of homozygosis as could be wished. We have merely to substitute the word "factors" or "genes" for "gemmules" to have virtually a statement in the form of the Mendelian theory.

Finally, Darwin says:-

"And, lastly, hybridised gemmules derived from both parent hybrids would simply reproduce the original hybrid form" (ibid.).

Here is what appears to be, and substantially is on its face, a Mendelian form of explanation of recombination in heterozygosis, with this difference: According to Darwin's conception, the "gemmules," or as we should say "factors," come over, D $\times$. Dr, from the respective parents in an already hybridised state, and give rise, simply by virtue of their all being there in a hybrid, to a complete bodily state of $D r$ - the hybrid condition-not, however, by means of segregation and recombination. Here is lacking, of course, the conception of separation and recombination according to the law of chance of $D$ and $r$, giving I $D D: 2 D r: 1 \quad r r$. Such an explanation could scarcely have been expected to be worked out short of an experiment such as Mendel's, involving actual counts. It does seem strange to us now, in view of the several times previously recurring observations by some five different breeders, including those of Goss and Knight, of the phenomenon of the appearance of different coloured peas in the same pod as the result of crossing, that this phenomenon should not have aroused curiosity and led to experiments on Darwin's part, for he refers to them all. However, in view of the fact that neither Nägeli nor Fockethe only investigators before 1900 who were acquainted with Mendel's papers at all-was particularly impressed with the importance of his experiments with peas, it is not surprising that Darwin should, among others, have failed to find the clue that Mendel did.

However, as a contribution to the development of the history of hybridisation, Darwin's application of his doctrine of pangenesis is highly interesting, showing the operation of an able mind, in the absence of adequate experimental data, in framing a conception of a theory of hybrids that comes surprisingly near being a statement of the present point of view as regards operation and, in the case of homozygosis, in regard to theory as well.

Department of Botany, Kansas State Agricultural College, June 24.

\section{Wild Birds and Distasteful Insect Larvæ}

Dr. W. E. Collinge gives in Nature of July 24 some most interesting details about the distastefulness of insects to birds. He observes that both the larva and imago of Abraxas grossulariata are eaten by various species. I would like to add the following observaNo. 2598 , VOL. IO3]
tions:-During the last few years I have bred several thousand larvæ, including those of $A$. grossulariata, in order to study their genetics. Owing to the impossibility of setting all the imagines, a certain number were set free as soon as recorded. In this way I have thrown out of my window imagines of the following species:-A. grossulariata, Spilosoma mendica (larvæ and imagines), and both type and melanic forms of Tephrosia consonaria, Boarmia consortaria, and $B$. abietaria. I have noticed the following points :- (I) The birds round the house, chiefly sparrows, would eat the imagines of all five species, but $A$. grossulariata the least readily, tearing off the wings and devouring the body on the spot (it-was too late in the year for them to be feeding young). (2) My larvæ of $S$. mendica were suffering from a disease (a filter-passer, I believe, for smears revealed no microorganisms), and when an entire brood was past hope I used to throw them into the garden. Some were dead and many dying, but they were cleared away in a few minutes, in spite of their evil smell. (3) The imagines of $B$. consortaria and $B$. abietaria were eaten with the utmost avidity. No sooner had one or two insects been thrown out than a number of birds would crowd round waiting for the next, and if this were hidden in the ivy round the house they would hunt for it until it was found. On one occasion some insects were hidden in a flower-pot on the window-sill, but the birds soon found them, and would afterwards return to the edge of the pot, as if waiting for more. These birds would even carry off dry pinned insects, possibly for their nests. The fact that birds will not eat $A$. grossulariata readily, but will eat the diseased larvæ of S. mendica, seems to support Mr. Speyer's view, especially since the parasites mentioned do not live in the alimentary tract. For this reason they contain no proteolytic enzymes, and can therefore be of no conceivable harm to voung birds.

Observations as to the extent to which birds prey upon the imagines of various species have a special interest, because those theories of mimicry which are based on natural selection demand some conscious selective agent such as birds, although there are very few actual observations to support such a conclusion. Evidence concerning European species is, of course. only of value by analogv.

3 Selwyn Gardens, Cambridge, August 2.

THE BRUSSELS MEETING OF THE INTERNATIONAI. RESEARCH COUNCIL.

THE Inter-Allied Conference on International 1 Organisations in Science, which met in Paris on November 26-29, 19r8, adopted a number of resolutions for constituting such organisations for the promotion of co-operation in scientific work, and appointed an executive committee to carry them out until the scheme was sufficiently advanced for the International Council to be convened and to assume its final form as a federation of National Research Councils.

This took place at a meeting which was held in Brussels on July i8-28, where the following countries and dominions were represented by their delegates: Belgium, Canada, France, Italy, Japan, New Zealand, Poland, Rumania, Serbia, the United Kingdom, and the United States of America.

On the morning of Friday, July 18 , the delegates met in the Palais des Académies, where King Albert was present. M. Harmignie, the 